\title{
Blind People's Multiple Identity and Impression Management in Bandung, West Java, Indonesia
}

\author{
Kadri $^{1}$, Deddy Mulyana ${ }^{2}$
}

\author{
${ }^{1}$ Faculty of Da' wah and Communication, State Islamic University of Mataram, Jalan \\ Pendidikan No. 35, Mataram, West Nusa Tenggara, Indonesia \\ ${ }^{2}$ Faculty of Communications Sciences, Padjadjaran University, \\ Jatinangor, Sumedang, West Java, Indonesia \\ Email: kadri@uinmataram.ac.id; deddy.mulyana@unpad.ac.id
}

\begin{abstract}
This research aims to uncover the multiple identities of 40 blind people and develop a model of their impression management that may be different from the impression management of nondisabled people. Blind people as subjects of this study are those who experience blindness in adulthood but were able-bodied before. Changes in physical conditions are followed by psychological changes that affect the way they communicate with their social environment, which is marked by impression management efforts. Using an interpretive perspective, more specifically a dramaturgical approach relying largely on observation as its method, the study reveals that the blind's impression management is related to their self-confidence. The lower self-confidence they possess, the higher effort of impression management they make. The blind's impression management is conducted in two strategies: first, by not using a personal front like black eyeglasses and a white stick; and secondly, by involving a performance team. These findings reinforce the distinction between the blind and the able-bodied people in their impression management. The nondisabled people usually use the personal front when managing the impression on the front stage. Based on finding that the blind's impression management is distinctive in nature, this study has enriched Goffman's dramaturgical theory.
\end{abstract}

Keywords: Blind People, Dramaturgical Perspective, Impression Management, Multiple Identity, Physical Stigma

\section{Introduction}

Having a healthy body is a dream of all humans. Such desires and expectations are a natural tendency because biologically the existence and survival of a person are also determined by the condition of his body, especially its parts that have a direct role in communicating like the eyes. In the context of communication, body is one source of nonverbal messages that is full of symbolic cues. Nonverbal cues are important in communication, especially face-to-face communication. Mulyana (2017:351) cites several related opinions on this subject. Birdwhistell states that $65 \%$ of face-to-face communication is nonverbal, and our face can create 250,000 different expressions.
Mehrabian noted that $93 \%$ of all social meanings in face-to-face communication were obtained from nonverbal cues.

The communicative function of the human organs will be more salient in the communication process if the organs have strategic functions and many benefits for human life. The eye is one of the organs of the body that functions as the sense of sight. In addition to having a vital biological function, eye also has a strategic social and psychological role. DeVito (2011:191) regards the eye as the most important nonverbal messaging system. Wenburg and Wilmot mention two functions of eye contact in interpersonal communication, namely; first, the regulatory function, to tell others whether or not we may relate to them; 
second, the expressive function, to tell others how you feel about them (Mulyana \& Kadri, 2019: 235).

Knapp (DeVito, 2011:191) mentions four functions of the eye as a nonverbal communication media; (1) seeking feedback, (2) informing others to speak, (3) hinting the nature of the relationship, and (4) compensating for the increased physical distance. In the context of communication (especially face-toface communication), the eye is one of the five senses that has a strategic function. Therefore, if one cannot see then many nonverbal cues from his communication partners cannot be interpreted, even though these cues are full of meaning. With these functions, the eye has an important role and contributes greatly to the ongoing human communication, let alone most of messages interpreted by the brain-derived from visual stimuli. With its vital functions, the eyes of people are very meaningful and valuable.

If the eye has a strategic role in human communication, then what about the communication done by people who suffer from blindness in adulthood. The old experiences and values that they used to have must be reconstructed according to the new physical condition. The process of reconstructing this new habit is coincided with the psychological turmoil blind people have experienced. Their physical condition is against their psychological desires. Therefore, blind people in adulthood are faced with a dilemma where on the one hand their physical condition has changed (from able-bodied to blind) but on the other side they desire to mask the new physical condition. In such a dilemmatic situation, the blind performs certain impression management when communicating and interacting with their social environment. The physical stigma attributed to blind people is predicted to affect the way they perform impression management. As Kuswarno (2009:102) argues, a different stigma attributed to a person will determine the nature of dramaturgical interaction in which the person is engaged.

Impression management consists of tactics used by the actors to cultivate certain impressions in certain situations to achieve certain goals. The impression management performed by the blind can be explained by the dramaturgical theory of Erving Goffman (1959). Goffman views that when humans interact with each other, he wants to manage the impression he expects to grow in others toward him, so that everyone is performing for others (Mulyana, 2018:150). The arena of life is according to Goffman like a stage play. Following this theatrical analogy, Goffman (1959: 109) speaks of the front region and the back region.

The front region refers to a social event that enables individuals to display their formal role. They are like playing a role on the stage in front of the audience. Meanwhile the back region is likened to a dressing room where the actors relax and prepare before playing a role on the front stage, which is usually more natural (Goffman, 1959:109-140). The front or back region in the context of Goffman's dramaturgical theory is not identical to a particular location or situation, nor does it refer to a fixed physical place. The division of the stage in the dramaturgical theory is more fluid in the sense that the determination of the stage 
will greatly depend on each actor. In fact, the same physical area can be interpreted as two different stages by two people. In other words, the back region for one person can be the front region for the other.

This study elaborates the motives, ways, and dynamics of blind people's impression management in the front region contrasted with what they do in the back region. In Indonesia this sort of study is scarce, otherwise nonexistent, since dramaturgical studies are dominated by political communication studies, as conducted by Priyadi (2018) who studied the dramaturgical performance of Anies Baswedan in his political campaign when running for the DKI governor in 2017, Fitri (2015) who studied the dramaturgical performance of Prabowo Subianto through Twitter prior to the presidential election in 2014, and Arrianie (2011) who studied how politicians utilized (mass) media as part of their dramaturgical performance. The physical stigma experienced by blind people makes their dramaturgical performance unique and different from the impression management performed by able-bodied people and from people suffering from other kinds of disability such as oligodactily sufferers as investigated by Sulaeman (2018).

This study also relates the physical stigma experienced blind people to their dramaturgical performance in the front region. Stigma is a more typical Goffman term that is more relevant to explain the phenomenon of visual impairment or other kinds of impairment. In relation to stigma, Goffman (1968:57) puts forward two stigma models, namely discredit stigma and discreditable stigma. Discredit stigma pertains to people who experience a real stigma that can be known to the 'audience' (social environment) such as disability, paralysis, blindness, polio and so forth. Discreditable stigma is a stigma that is unknown to the audience members or cannot be perceived by them, such as a stigma attributed to a homosexual, an ex-murderer, an ex-robber, and so on.

The concept of stigma that Goffman describes is related to the problem of impression management which becomes the main concept of dramaturgical theory. Each person who is stigmatized (both discredit stigma and discreditable stigma) has basic dramaturgical issues when dealing with his social environment, because in an attempt to present himself, sometimes the actor faces a gap between the self-image he wants others to see and his true identity. Following Goffman, for someone who has a physical stigma, the dramaturgical problem is how to manage the tension that comes from the fact that others know the physical defects of the actor (Mulyana, 2018:159). Connecting the concept of stigma to the dramaturgical perspective, this study aims to construct a model of impression management of blind people who have a physical stigma due to their eye dysfunction

\section{Method of Research}

This research is the result of research on 40 blind people ( 9 females and 31 males), residents of the blind rehabilitation center "Wyata Guna" Bandung - West Java, Indonesia, who suffered from blindness in adulthood as research subjects. A larger proportion of them (32 people) come from 
West Java, the rest from other provinces: East Java, Jambi, East Kalimantan, West Sumatera, and Bali. The informants began to suffer from blindness when they were young (the youngest was 18 and the oldest was 36 at the time of the initial research) with the causal factors being accident, chataract, and glucoma. Twenty one informants were private company employees and 19 were school and university students when the tragedy took place. Four informants were widowers, one was a widow, two were married, and 33 were single.

The study used a qualitative approach according to the interpretive perspective, particularly the dramaturgical approach. Data were collected by interviews, observation, and documentation mainly in the form of pictures of the blind's impression management in the public space. Although much of the data is derived from larger research that took place years ago, more recent research was conducted in January and February 2018 to revisit the research site, to meet some of the old subjects, and to "renegotiate" the findings of the research.

To some extent the study utilizes the five stages of data analysis as put forward by Creswell (2016:277), namely: preparing data, reading data, coding data, developing themes, and interpreting the themes emerging from the data. However, to a larger degree the study relies on the dramaturgical tradition of data analysis based on three main concepts: impression management, the front region and the back region. The model represented in this article constitutes the researchers' interpretation of the research findings.

\section{Results and Discussion}

Permanent and Situational Identity in Blind Impression Management

Based on our observation of and interviews with all the informants, in their interaction with others the blind have used two identities: permanent identity and situational identity. Permanent identities are related to the physical condition, while situational identity is related to the psychological desire to be ablebodied. Although physically they are labeled blind, it does not mean they psychologically accept that identity. In certain situations and based on certain motives blind people often object to being nicknamed blind so they as much as possible hide their blindness and act as if they are able-bodied. This effort is known as the representation of situational identity through the management of an impression amid permanent identity that continues to be inherent in the blind's life.

Blind people realize that their permanent identity is always embedded in them so that in certain moments they cannot avoid that identity from the knowledge of others. The permanent identity that a blind person is aware of in this article is closer to the term of an objective identity as defined by Berger and Luckmann (Romli, 2015:10), that is, as an identity derived from the legitimacy of social structure and has become a common knowledge of the majority of society.

In general, blind people have been aware of their permanent identity since there is medical certainty that their eyes cannot be cured again. The awareness continues to be believed in line with the legitimacy that is continuously given by the environment, including the 
willingness to enter rehabilitation. Awareness of the permanent identity is what makes them sometimes no longer question the identity, so in a certain context, they can interact with others by displaying themselves as they are and without any burden.

Blind people usually present themselves as they are in front of their community. They do not have any psychological burden when interacting in a community that suffers from the same ailment, or in front of able-bodied people who can see (such as their mentor) who have understood their condition. This phenomenon is a manifestation of the presence of self or objective identity in their interaction with others. No specific strategies were found to be conducted by the blind when communicating with their fellows in their community. Some of the blind encountered by the researchers at Bina Netra Social Home (PSBN) Wyata Guna, Bandung - West Java, acknowledge that they considered it like a home where they lived with their own family.

Situational identity is identical with the subjective identity; it is an identity that is presented or constructed by blind people in a situation and with certain motives. The emergence of situational identity is motivated by the desire of the blind to cover their permanent identity. Therefore, the emergence of situational identity is characterized by their efforts to construct certain realities, which, among others, by managing the impression that their communication partners are confident that they are not blind. These communication partners may include strangers or even old friends who do not know his new identity as blind. This impression management is have done especially when the blind is not ready psychologically to accept blindness as an objective identity.

\section{The existence of a personal front in the Im- pression Management of Blind}

The way the blind people under this study communicate on the front stage in a particular context is different from the way they do when they are on the back stage. The impression management of these visually impaired people can be seen when they communicate with others in the public sphere or which Goffman (1959:109-110) calls the front region. One of the strategies of impression management is have done by the disabled when they interpret the existence of a personal front.

Goffman (1959:34) divides the front region into two parts: setting and personal front. Setting is a physical situation that must exist when the actor has to perform. While a personal front consists of tools or equipment brought by the actor into the setting, the actor's verbal language and body language can be also categorized as a personal front.

Goffman does associate a personal front in the context of the front region with nondisabled people such as actors who are known for their professions and distinctive attributes, such as a doctor in his white coat. However, the researchers argue, the meaning of personal front proposed by Goffman can be used also in the context of physical stigma performance of disabled people such as those who are visually impaired. Blind people have a physical stigma related to the distinctive personal front, such as rods and sunglasses, tools usually identified with blind people. Nevertheless, each blind person has a different way of managing the 
impression through those two personal tools.

Blind people who experience a physical stigma, tend to manage the impression that is different from what is done by a nondisabled person who has a certain profession. In the front region, blind people do not use personal fronts like sunglasses. This is different from doctors for example who generally wear a white coat in the practice room setting. Not wearing sunglasses by certain blind people can be considered as a form of their impression management so as not to be identified as blind. In other words, they want to build a self-image in the presence of others in the hope that everyone who sees them does not judge them as blind (see figure -1).

The impression by not wearing sunglasses (as a personal front) is usually done by blind people who have the shape (performance) eyes that still look good like the eyes of a nondisabled person, such as eyes that are not watery, or who have intact eyeballs. People who see a blind person with a good eye shape are often fooled by thinking and treating him as a person who can see. The decision not to wear sunglasses by some blind people who have a good shape of the eye is not without a motive. Such an impression management is an attempt to present self in the front region in the hope that his communication partner considers him a nondisabled person.

In addition to managing the impression of not wearing sunglasses in public, some blind people who have a 'normal' eye shape sometimes wear clear glasses, which seem to look like spectacles. The use of these clear glasses also has certain purposes, in which the blind want to build the impression that his eyes are not 'blind' but only nearsighted and so he wears eyeglasses.

Some blind people avoid wearing sunglasses in order to give the impression to others that they are not blind. But other blind people wear sunglasses as a personal front

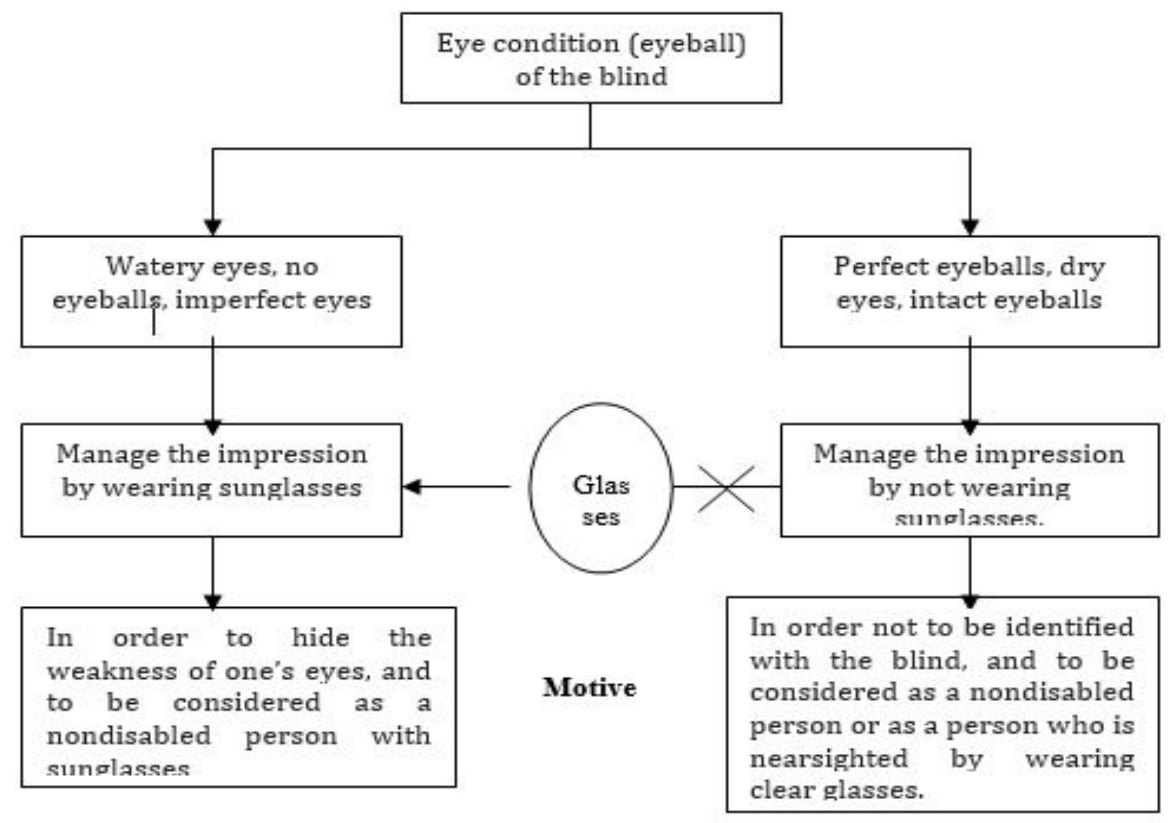

Figure-1: Double Existence of glasses in impression management of blind people 
when dealing with others. In one observation that the researchers once did, the blind wearing sunglasses were those who had visible unhealthy eyes, such as persistent aquatic eyes, eyes with no eyeballs, or eyeballs that stick out, and various other forms of the eye that are not normal.

Sunglasses were not used at all times by the blind. When they are in a dormitory with their friends, sunglasses are not worn and they do not feel they have any burden despite interacting with watery eyes, or without eyeballs. The dormitory and their presence among their blind fellows are the backstage settings for them. They can present themselves as they are, with no engineered impression management elements, since they know that their friends are unlikely to know their physical appearance due to the latter's blindness.

The blind's appearance immediately changes when they are in the presence of others outside the blind community (PSBN Wyata Guna-Bandung), both in the complex area of PSBN Wyata Guna - Bandung and other locations outside the complex area which have become the front region. In daily life in the dormitory, some blind people who never wear sunglasses, immediately wear them when attending an event involving outsiders, in order to hide the weak shape of their eyeballs. In addition to this motive of wearing sunglasses, they hope that others will see them as wary people who wear sunglasses.

In addition to sunglasses, objects or other tools commonly identified with the blind are white sticks. Basically, the stick for the blind is a tool used to help walk. The stick is so important for the visually impaired, that PSBN Wyata Guna Bandung as one of the blind rehabilitation institutions has distributed one stick to each blind person there, and teach them techniques to use the stick.

In addition to finding direction, the use of the stick by the blind can be a reference for people without disability to determine that a person is blind. For example, vehicle users may be cautious when someone is crossing the street with a stick, or a cautious person gives priority and special treatment to a person using a stick in a public place.

The existence of a white stick is treated differently from sunglasses by the blind. The blind often avoids using the white stick when wanting to manage the impression that he is not blind. Based on the results of the study, the researchers found at least two blind mobility strategies outside the rehabilitation complex without using a stick; first, by utilizing people or other blind people who have low vision in order to be free from the use of sticks and can walk while holding on to people as if they were nondisabled people; second, by hiding the stick behind the waist or in the bag, but use it at a critical moment like when they need to cross the road. After that they put it back. Both strategies of managing the impression management are intended to make others not to perceive them as blind people often associated with the white stick.

Most of blind people in this research utilize the first strategy by taking advantage of nondisabled people when they have 
activities out of the rehabilitation area. If they want to take a vacation or just come home on the weekend, one of their family members picks up and drives them back to the dorm. They never use a stick while among nondisabled people. This reality shows that the management of the impression by not using the white stick is often simultaneously coincides with the utilization of the people who are their significant others. In Goffman's dramaturgical perspective, these people belong to the team of impression management.

\section{The Use of Teams in Blind People's Impres- sion Management}

Blind people are social beings who have a community and always build relationships with others. Such relationships may be familial, formal, or emotional. Since childhood, they have gathered in families. Family members will even be important partners for them after blindness afflict them in adulthood. These partners are not just chatting companions, but partners who can be guides, patrons, and other roles that contribute to their relationships. Family members become companions and protectors during the treatment process. Community instructors, counselors, social workers and institutional workers become their partners and educators during the orphanage. So do their lovers (especially nondisabled girlfriends) who become loving, compassionate and motivating partners.

The close and togetherness of blind people with their communication partners enable them to understand each other, including understanding the problems of life. Moreover, they can work together as a team to build certain impressions in the front region with specific goals. The use of teams in impression management has become one of the focuses of dramaturgical studies. Goffman (1959:85) mentions a team that dramatizes an activity. In the context of this study, among the significant others who become the performance team in the show (impression management) are especially blind people's family members and lovers. Each team with different relationships with the blind has different and similar scenarios in a 'dramatic' show with the main player being the blind.

The family is the first impression management team to join in the show. A drama is acted by the blind and his family which is different from the other dramas played by the people in general. While the show acted by able-bodied people tries to display the impression based on the status and role understood by the audience, the show played by the blind and his family intends to cover up the actual role, by displaying the old activities of the blind when he still could see, such as how to walk and how to guide him in order not to be visible as blind.

The involvement of the family in managing the impression is not just how to organize appearances such as how to walk and how to guide the blind, but also how to use attributes or personal fronts (like sticks) by the visually impaired. One of the blind people recounted that his wife and children forbade him to use a stick when he was invited to go out in the recreation area with the family. 
The impression management team of the blind not only comes from their family but also consists of their lovers or close friends. The impression management by the blind with a lover or with a friend is not different from the way and strategy done at the time with his family. Usually, an impression management involving lovers and friends as a team takes place when they visit a single place or public facility. In case the blind is a man, her lover can maximally cover the identity of the blind partner by continuing to hold her while she is in the public sphere.

In dating the able-bodied person, the able-bodied is usually more agile, especially in guiding the mobility of his or her blind lover. One moment of togetherness that researchers saw was when the blind were escorted home by their lovers in the complex PSBN Wyata Guna Bandung after a walk or a trip from somewhere outside of the complex. Sometimes researchers found changing facial expressions and different ways of touching by the couple, one of which was a nondisabled person, when they met other people on the street. They managed the impression by letting the blind walk in a usual way, without a serious touch.

The overall impression management of the blind after blindness takes place in adulthood is illustrated diagrammatically in figure-2. As previously described, impression management is one of the typical communication realities that can be found in blind people's communication, especially with outsiders or strangers. In this study the impression management by blind people is merely due to the blindness associated with a physical stigma. Therefore, these findings justify Goffman's assumption which says that for someone who has a physical stigma; the dramaturgical problem is to manage the tension that comes from the fact that others know the physical defect of the actor (Mulyana, 2018: 159).

The impression management of the blind always begins with the problem of presenting themselves as well as their selfimage in front of others who have already stigmatized them. So, the impression management of a blind person cannot be separated from others' judgment of him that he understands. Mead's theory of selfconcept which forms the core of the theory of symbolic interaction as well as the guide of Goffman's dramaturgical theory applies in this respect. According to Mead (Mulyana, 2018: 111), self concept is a process derived from the individual's social interaction with others, while according to Cooley's Looking-glass-self concept, the individual's self-concept is significantly determined by what he thinks of other people's thoughts about him.

The concept of self and the impression management are strongly related when explaining the reality of the impression management of the blind. The impression management arises when a blind person has poor self-assessment or a negative selfconcept. When a blind person is not ready and will not accept his blind identity, then at the same time he performs an impression management by displaying a situational identity, by managing certain impressions so that other people consider him as a respected 


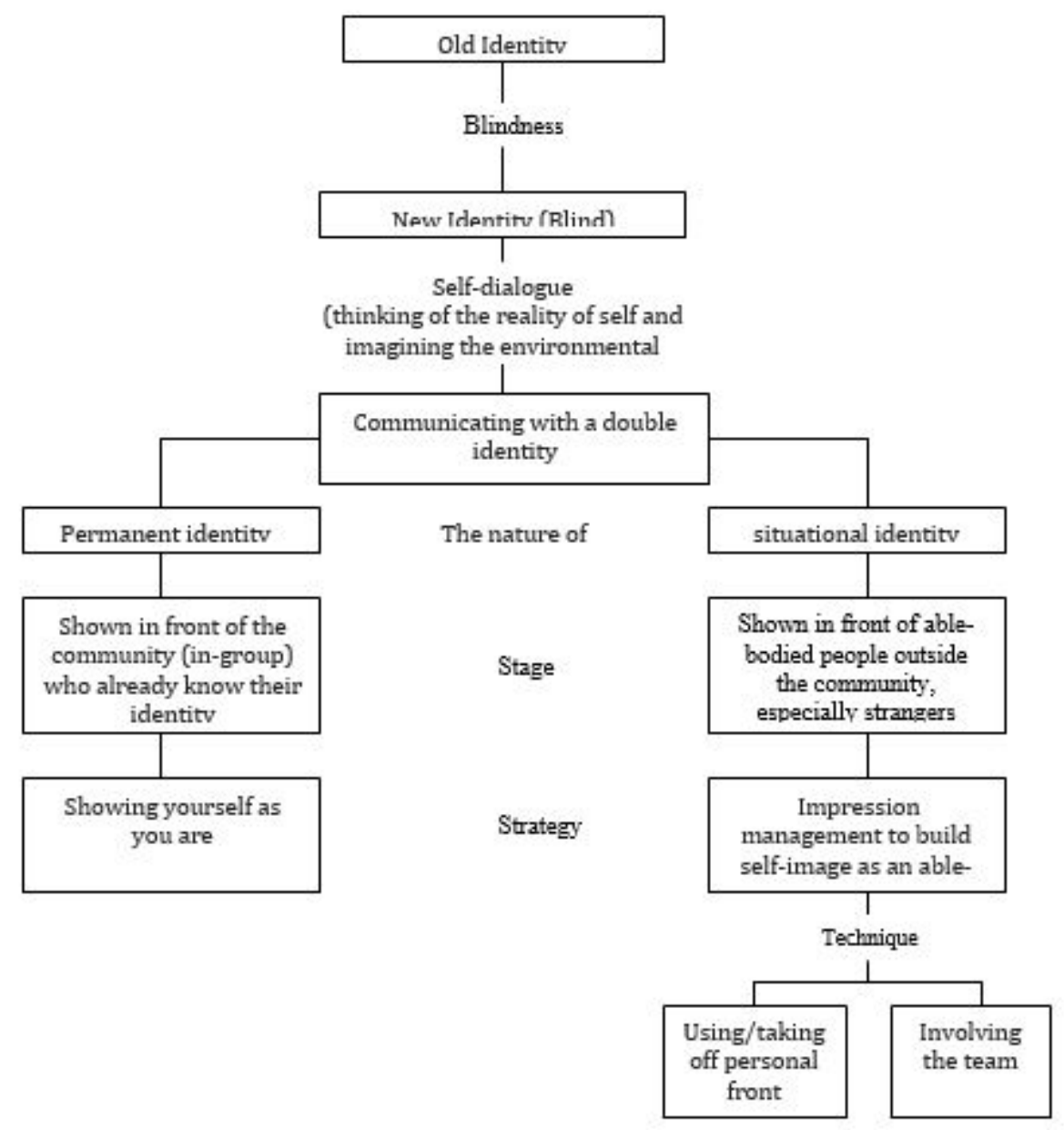

Figure-2: Model of blind people's impression management

Source: Research Findings, 2018

person. Our proposition is that there is a relationship between the self-confidence and the impression management made by the blind. The less the blind's self-confidence, the more often they manage the impression. Conversely, the higher the blind's self-confidence, the less likely they manage the impression.

As described earlier, this study found at least two techniques or strategies of impression management by blind people to build a good self-image in the front of their communication partners.

First, the impression management through the use and the negligence of personal fronts suit the needs of a blind person. For example, sunglasses are not all worn by the blind, but are only worn by blind people who have unhealthy eye shapes and unhealthy eyeballs, such as watery eyes and eyeballs that no longer exist. So the blind wear sunglasses as a tactic to conceal the weakness of the eyes. Blind people usually do not want to be seen as blind by others, so that they may alienate themselves from the two personal fronts attributed to them such as sunglasses and white sticks. This kind of impression management by the blind is different from the impression management 
by general people. Personal fronts for ablebodied people become a weapon for them to present themselves (managing impressions) in front of others. In contrast, the blind with a physical stigma manage the impression by avoiding the use of personal fronts in front of others or in the public space. These findings are different from Goffman's assumptions related to the role of personal fronts in impression management. Goffman as quoted by Mulyana (2018:152) called the use of personal front as part of someone's impression management in the front region. On the contrary, this study indicates that the personal front is a tool or artifact avoided by the blind in the front region. In other words, Goffman's impression management model that uses a personal front is not "suitable" for a disabled group such as the blind.

Second, the blind sometimes use the team (in collaboration with others) in managing the impression. Family members and lovers or close friends are the two communities used to be collaborators of the blind's impression management team. Referring to the function of the team that Goffman (1959:85) calls the performance team, it is a team that dramatizes an activity; the roles of the blind's impression management team are like a drama team featuring certain plays to get certain impressions in front of the audience. Family members such as the blind's parents sometimes help the blind's mystification to avoid being monitored by others. Even if the blind actor must be present in public, other team members such as family members and lovers make efforts to help and guide him with certain techniques so as not to make an impression that the actor is blind.

Impression management strategies implemented by the blind are conducted in front of outsiders who do not belong to their family or community. Based on this reality a proposition can be formulated that the blind's impression management takes place only in front of people outside their community, but not in front of their blind fellows and ablebodied insiders with whom they regularly communicate. Referring to the meaning of the region proposed by Goffman (1959:109), it can be said that in front of general people, the blind use their front region as their impression management, while their presence among of the blind community or their family members are their back region.

\section{Conclusion}

Impression management by the 40 blind people as subjects of this study begins when blindness befalls. The blind people begin to think about their new identity and imagine the response of others. As social beings they must interact in their social world even though psychologically they are not confident with their new status. It is in this dilemmatic condition that a blind person uses a double identity that is a permanent identity as a blind person and situational identity constructed subjectively based on his motive to show himself as a perfectly normal, non-blind human being.

Impression management by the subjects of the study is taking place when they present themselves with a situational identity. The impression management is conducted in the front region in the public space and in front of strangers. The back region is used 
in front of their family members and in the rehabilitation center where blind people present themselves as they are. Impression management is accomplished in two strategies by utilizing personal fronts such as sunglasses and white sticks used flexibly according to their subjective motives and desires to prevent strangers to see them as blind. The use of personal front is supported by the second impression management strategy, that is, the use of a team such as family members and close friends.

This study has found a distinctive dramaturgical performance managed by blind people under this study which is different from the dramaturgical performance managed by nondisabled communities. Therefore, it is not exaggerated to say that this study has contributed to Goffman's dramaturgical theory. However, this study is not meant to be generalized into other communities of blind people in Indonesia. It is for this reason that other studies based the same theoretical perspective are worth conducting to examine other tactics of impression management performed by other communities of blind people in the country which might be more appealing.

\section{References}

Arrianie, L. (2011), "Media Darling dan Impression Management Politik Politisi." Media Kom: Jurnal Ilmiah, Vol. 4, No. 8, pp. 67-80.

Creswell, J.W, (2016), Research Design: Pendekatan Kualitatif, Kuantitatif, dan Mixed, Yogyakarta: Pustaka Pelajar
DeVito, J.A. (2011), Komunikasi Antarmanusia. 5th.ed. Terjemahan; Agus Maulana (et.al.). Jakarta: Karisma Publishing

Fitri, A. (2015), "Dramaturgi Pencitraan Prabowo Subianto di Media Sosial Twitter Menjelang Pemilihan Presiden 2014." Interaksi: Jurnal Ilmu Komunikasi, Vol. 4, No. 1, pp. 101-108.

Goffman, E. (1968). Stigma. Great Britain: Cox \& Wyman.

Goffman, E. (1959). The Presentation of Self in Everyday Life. Great Britain: Cox \& Wyman.

Kuswarno, E. (2009). Metode Penelitian Komunikasi: Fenomenologi, Konsepsi, Pedoman, dan Contoh Penelitian. Bandung: Widya Padjadjaran.

Mulyana, D. \& Kadri, (2019), "Identity Transformation of Blind People with Blindness in Adulthood in Bandung", MIMBAR, Vol. 32 No. 1st. pp. 235-244

Mulyana, D. (2018). Metodologi Penelitian Kualitatif: Paradigma Baru Ilmu Komunikasi dan Ilmu Sosial Lainnya. Bandung: Rosda.

Mulyana, D. (2017). Ilmu Komunikasi: Suatu Pengantar. Bandung: Rosda.

Priyadi, C. (2018), “Analisis Dramaturgi Penampilan Anies Baswedan dalam Kampanye Pilgub 2017.” Jurnal Pustaka Komunikasi, Vol. 1, No. 2, pp. 339 - 348

Romli, K., (2015), “Akulturasi dan Asimilasi dalam Konteks Interaksi Antar Etnik", Ijtimaiyya, Vol. 8. No. 1. Pebruari.

Sulaeman, (2018), "Dramaturgi Penyandang Oligodaktili." Jurnal Aspikom, Vol. 3, No.4, pp. $602-674$ 